\begin{tabular}{|c|c|c|}
\hline Beitr. Ent. & Keltern & ISSN 0005-805X \\
\hline $\mathbf{5 8}(2008) 1$ & S. $211-222$ & 15.07 .2008 \\
\hline
\end{tabular}

\title{
Houseflies of the Tristan da Cunha Islands: new records, including the first for Fannia albitarsis STEIN, 1911
}

\author{
(Diptera: Fanniidae, Muscidae)
}

With 3 figures

Christine Hänel and Adrian C. Pont

\begin{abstract}
Summary
Information about the Fanniidae and Muscidae Houseflies of the south Atlantic island group of Tristan da Cunha, from the earliest records to the most recent findings, is presented and discussed. In total, five species belonging to four genera are recorded. This includes the finding for the first time of Fannia albitarsis Stein, 1911 in the archipelago and Muscina stabulans (FAllén, 1817) on Nightingale Island. Based on material collected in 2005 from the two northern islands, Tristan da Cunha and Nightingale, records and notes are given on four species. A discussion of the correct taxonomic rank of Coenosia trina WiedemanN, 1830 is given. The apparent proliferation of this species, and the possible implications that this may have on endemics, is noted.

\section{Zusammenfassung}

In der Arbeit werden historische und aktuelle Funde von Hausfliegen der Familien Fanniidae und Muscidae auf den Inseln der Tristan da Cunha-Gruppe im Südatlantik zusammengefaßt und diskutiert. Das aktuelle Material wurde 2005 auf den nördlichen Inseln, Tristan da Cunha und Nightingale, gesammelt. Insgesamt sind fünf Arten in vier Gattungen nachgewiesen, einschließlich der Erstnachweise von Fannia albitarsis Stein, 1911 innerhalb des Archipels und von Muscina stabulans (FAllén, 1817) auf der Insel Nightingale. Die korrekte taxonomische Einordnung von Coenosia trina Wiedemann, 1830 wird diskutiert. Auf die offensichtlich starke Verbreitung dieser Art und den möglichen negativen Einfluss auf die heimische Fauna wird ebenfalls hingewiesen.
\end{abstract}

Key words

Diptera, Muscidae, Fanniidae, Housefly, Lesser Housefly, Stable fly, Tristan da Cunha, Nightingale, Gough, Inaccessible, Island, South Atlantic.

\section{Introduction}

The islands of the Tristan da Cunha archipelago were discovered by Portuguese explorers, Gough in 1505 and the northern three islands in 1506 (Ryan \& Glass, 2007). Situated in the South Atlantic between $37^{\circ} \mathrm{S} ; 12^{\circ} \mathrm{W}$ and $40^{\circ} \mathrm{S} ; 09^{\circ} \mathrm{W}$ (see description with locality map in HäNEL \& Heyne, in press, and further details on Nightingale in HäNEL \& HAENNI, 2007), the first recorded landings were made in the 17 th century by European traders en route to the east. In the 18th century, visits were mainly by sealers, many from the Americas, who lived on the islands for the 
purpose of exploiting the animal resources. These visits together with castaways and shipwrecks formed the first unnatural bridges to the Tristan territory. Through them, plants and animals were purposely or unwittingly introduced that under natural conditions would not be able to cross the vast expanse of ocean that separates the Island group from the nearest continental landmasses. Amongst the introduced invertebrate species are likely to have been flies that could well have included members of the family Muscidae.

Flies of the families Muscidae, commonly referred to as 'House flies', and Fanniidae, generally known as 'Lesser Houseflies', are thought to have established themselves at Tristan da Cunha well before the first settler did in 1811. The earliest 'evidence' of this appears to be an account published in 1818 that records the observations of Captain Dugald Carmichael, who stayed on Tristan da Cunha from 27 November 1816 to 30 March 1817 with the British garrison sent to annex the Island. According to Carmichael (1818: 497-498): "... the only insects I observed are three small species of Curculio; four of Phalaena; one of Hippobosca; two of Musca; and one of Oniscus"... "The common window-fly of the Cape was not observed until two months after our arrival; but before I left the island, it had begun to be troublesome." At this distance of time, it is not possible to identify the species of Musca mentioned by Carmichael, nor has his Musca material been located. The concept of Musca in 1818 was considerably broader than it is now, including many of the common Calliphoridae as well as species of the presentday tribe Muscini of the Muscidae. Whilst Carmichael very probably did observe Musca domestica Linnaeus, this cannot be certain, and the identity of his second "Musca" must remain doubtful, though we put forward the suggestion that it may well have been the introduced calliphorid greenbottle, Lucilia sericata (MeIgen, 1826), which Frey (1954) records from Tristan, Nightingale, Stoltenhoff and Inaccessible islands.

We also note that the type of the endemic Tristan dolichopodid Medeterus (now Hydrophorus) carmichaelii WALKER, 1849 originally formed part of the collection of the Edinburgh entomologist W. E. LEACH (1790-1836) and then went with his collection to the Natural History Museum, London, in 1826 (Horn \& KaHLE, 1935: 151). However, our searches at that museum have not located any Muscidae or Fanniidae collected by CARMiCHAEL that may formerly have been part of the LEACH collection.

It is also not possible to offer any definitive suggestion as to the identity of CARMICHAEL's "common window-fly of the Cape". However, it should be noted that Christopherson (1940: 199-200), the leader of the Norwegian Expedition to Tristan da Cunha in 1937-1938, referred to plagues of flies on the beaches which also entered the houses ("the window-panes were sometimes black with them"), and these are very probably the species that CARMichael called his "window-flies". We believe that they were swarms of the anthomyiid Fucellia tergina (ZETTERSTEDT, 1845), which was recorded from Tristan by FreY (1954: 42) as Fucellia maritima (HalidAY, 1838). This is an abundant seashore fly with larvae that live in decaying seaweeds, which often reaches astronomical numbers, and FrEY (l.c.) included the following entries in his list of specimens of maritima: "Tristan da Cunha: 5.XII.1937, ca. 50 Ex. 'The Expedition-building. Collection made indoors in our newly-built home, about 20 metres above sea-level' .... 10-11.I.1938, zahlreiche Exemplare. 'The mountain-plateau towards the West. Collected inside the tent and in the nearest environments about 600 metres above sea-level.'". These observations suggest that the species has a propensity to enter buildings and shelters, and offers support for our suggestion that this species is CARMICHAEL's "window-fly". Whilst F. tergina is not known to occur on the South African coast, the closely similar Fucellia capensis SCHINER, 1868 is a widespread and common seashore fly in southern Africa and, in the early 19th century, would certainly not have been distinguished from F. tergina. 
Some 57 years later, Dr. Rudolf von WillemöEs-Sunm, the entomologically orientated 'naturalist' on the H.M.S. Challenger, spent a few hours ashore at Tristan, Inaccessible and Nightingale Islands between 15 and 17 October 1873, collecting 'everything he could find'. In a preliminary report published before the voyage had ended, von Willemöes-Suнm (1876: 583-585) lists the taxa he collected. Under flies he states: "Diptera. - 1. Muscid, everywhere". Amongst the many accounts that resulted from the Challenger voyage, Professor Henry Moseley (1892: 115-116), confirmed: "There are ... a Hippobosca, Musca, and Tipula, mentioned by Captain Carmichael as found in Tristan da Cunha; we found them also...".

The first solid evidence of Muscidae (including Fanniidae) on the Tristan da Cunha archipelago was made available through the specimens collected during the Norwegian Expedition to Tristan da Cunha in 1937-1938. The findings amounted to two species; the Lesser Housefly Fannia canicularis (Linnaeus, 1761) and the Stable fly Muscina stabulans (FAllén, 1817), both cosmopolitan tramps typically associated with human settlements (FrEY, 1954). Subsequently, the Gough Island Scientific Survey, 1955-56, collected the first record from Gough Island, the fanniid F. canicularis (OLDROYD, 1958). Since then updates involving the Muscidae and Fanniidae have resulted from the following three surveys: the Royal Society's Expedition to Tristan da Cunha, 29 January to 20 March 1962 (BAIRD, 1965; HoldGATE, 1965); a multidisciplinary floristic-faunistic study on Inaccessible Island (including one day on Nightingale Island), October/November1989 (Carvalho et al., 2003); and the Gough Island Terrestrial Invertebrate Survey, September 1999 to September 2001 (Jones et al., 2003).

This paper is based primarily upon a collection made on Tristan da Cunha and Nightingale Islands in early 2005 (HäNEL, 2005). The collection formed part of a brief Invertebrate project that was inserted into a larger programme entitled "Empowering the People of Tristan da Cunha to Implement the Convention on Biological Diversity [CBD]" (RSPB, 2004-2005). Birds, mammals, and vegetation were the key areas of focus. Realising the gaps in invertebrate knowledge, a small component was slotted in to address this neglected group within the northern islands of the archipelago. The identification of the specimens collected was pursued beyond the boundaries of the project and has brought new information to light about the Muscidae and Fanniidae, including a species not previously recorded from the archipelago and a new island record. The findings of the 2005 collection together with a synthesis of existing information are here presented, in order to provide an overview of the status quo of the Muscidae and Fanniidae as currently known for the archipelago.

\section{Material and methods}

The fieldwork was conducted by C. H. on Tristan da Cunha (hereinafter referred to as 'Tristan') and Nightingale Islands between early February and the beginning of April 2005. The majority of the time was spent on Tristan and a period of two weeks on Nightingale. Sampling was random and opportunistic, but focused on trying to cover the major habitat types represented. On Tristan, 23 sites at eight different locations were sampled. Most of the areas sampled (62.5\%) were in the lowlands, although a few $(12.5 \%)$ were on the slopes above, and a couple $(2.5 \%)$ were on the plateau. No higher altitudes were sampled. The habitats entailed principally agricultural crop and pasturelands, some 'intruded' fern-bush communities, and a boggy wetland (Soggy Plain). On Nightingale 10 sites were sampled in two main regions. The latter comprised the lowland areas dominated by tussock grasslands and the higher central wetland areas. Muscidae and Fanniidae 


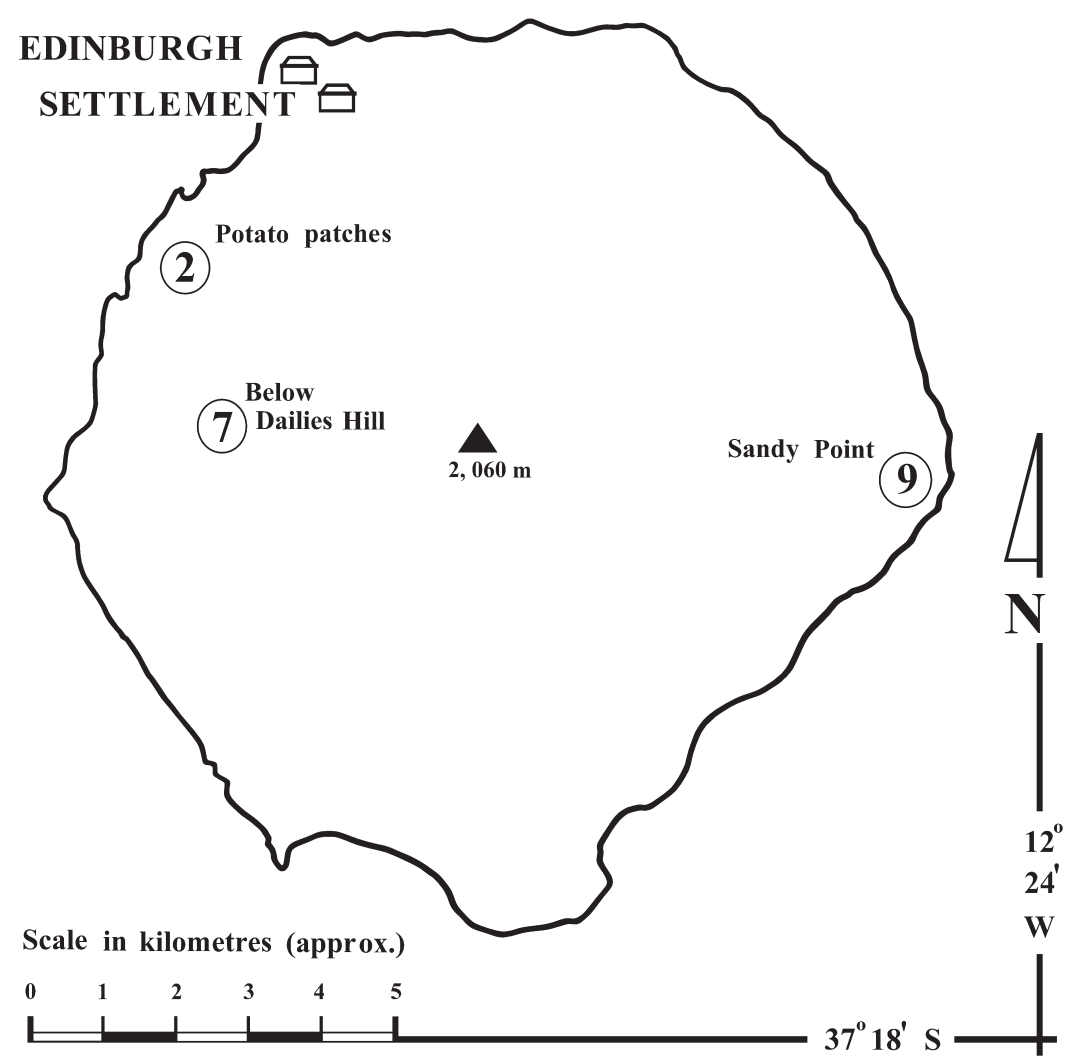

Fig. 1: Places on Tristan da Cunha Island where Muscidae and Fanniidae were collected in 2005. The circled digits 2, $7 \& 9$ represent the sites where samples were obtained. Map drawn by Ch. Hänel.

were obtained at three of the eight Tristan localities (see Fig. 1) and at both high and low altitude localities on Nightingale (see Fig. 2). Flies were principally collected using Malaise traps. Sweep netting was also employed but yielded only limited specimens. All specimens, bar three pinned individuals from Tristan, were preserved in $70 \%$ ethanol. The material was later identified by A.C.P., using standard methods and literature (e.g. Hennig, 1955-1964; Emden, 1940). Some specimens were dried and mounted, and some were dissected. Representatives of each species from both Tristan and Nightingale are deposited in the Agriculture and Natural Resources Department, Tristan da Cunha, and the IZIKO South African Museum, Cape Town, South Africa.

\section{Results}

In total four species, two of Muscidae and two of Fanniidae, were collected in 2005. These are: Coenosia trina Wiedemann, 1830, Muscina stabulans (Fallén, 1817), Fannia albitarsis Stein, 1911 and F. canicularis (Linnaeus, 1761). Collecting details for these species are summarised below together with the relevant data pertaining to the sites (e.g. locality, habitat, and vegetation types), along with information relevant to the species status and general habits. 


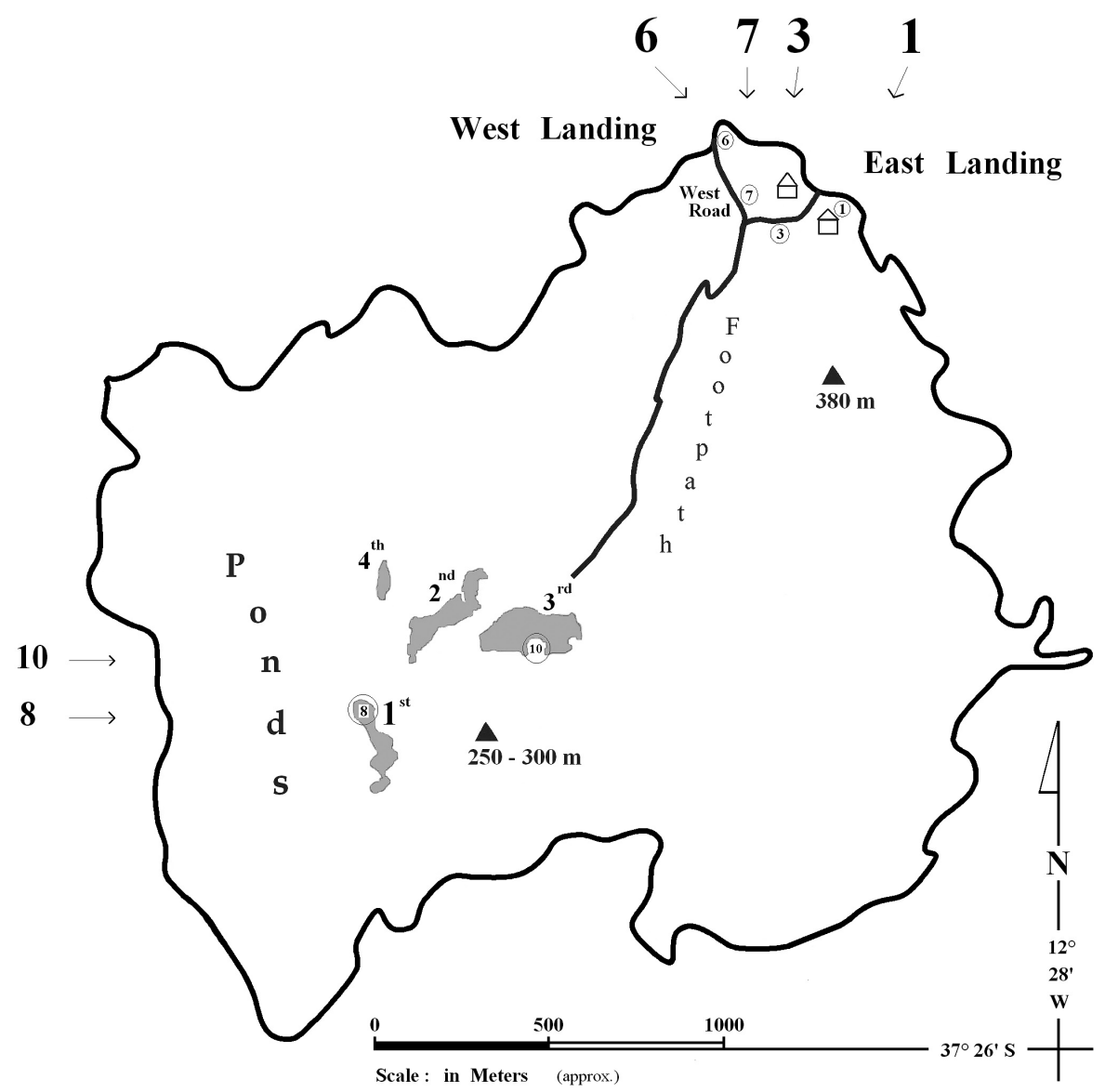

Fig. 2: Places on Nightingale Island where Muscidae and Fanniidae were collected in 2005. The expanded digits on the perimeter point to the sites (circled) where samples were obtained. Map drawn by Ch. Hänel.

\section{FANNIIDAE}

\section{Fannia albitarsis STEIN, 1911}

New record for the Tristan da Cunha archipelago (see Fig. 3).

Widespread in South America (CARvalho et al., 2003: 7), and introduced into South Africa (PonT, 1980a: 719), Amsterdam Island (Pont, 2006: 318), Australia, New Zealand (Pont, 1989: 700) and Fiji. Adult flies can be easily recognised using the key and illustrations in Pont \& Carvalho (1994: 231, figs 1-3): particularly characteristic are the ornamentations of the fore tarsomeres and hind femur in males The larvae are saprophages, and have been reared from birds' nests, poultry and sheep dung, and carcasses of a stingray, fish and a bird (HollowAY, 1985: 253).

Seven specimens ( $4 \sigma^{\star} \sigma^{\star}, 3$ ㅇ \% ), collected on Tristan and Nightingale Islands in 2005:

TRISTAN DA CUNHA, west of Edinburgh village, potato patches, cultivated cropland, potatoes, vegetation and cattle grazing, $\pm 127 \mathrm{ft}$., 3709'06"S 12³4'26"W, 07-12.ii.2005, site 2, sample 14c, C. HäNel, 1 \% (pinned) (see Fig. 3). 
NIGHTINGALE, West Road, path inland from landing, tussock grassland some Scirpus and alien spp. in path, $37^{\circ} 25^{\prime} 02^{\prime \prime S} 12^{\circ} 28^{\prime} 66^{\prime \prime W}, 28-29 . i i i .2005$, site 7, sample 19a, C. Hänel, $4 \delta^{\star} \sigma^{\star}$, 1 ㅇ (alcohol).

NIGHTINGALE, Herbert's hut site, East Landing area, tussock grassland and alien veg. along path, 37²5'08"S 12²8'53"W, 29-31.iii.2005, site 3, sample 20a, C. Hänel, 1 ㅇ (alcohol).

\section{Fannia canicularis (LINNAEUs, 1761)}

First recorded by FreY (1954: 43) from Tristan, Nightingale and Inaccessible Islands. Oldroyd (1958: 79) then recorded it from Gough Island. These records are summarised in PonT (1977: 125). Additional finds are reported from Gough by Jones et al. (2003: 255) and from Inaccessible by Carvalho \& Couri (1999: 211).

Cosmopolitan in distribution. It has been reared from a wide range of decaying animal and vegetable matter, fungi, manure, etc, where the larvae are saprophagous.

One female specimen collected on Tristan Island in 2005:

TRISTAN DA CUNHA, up Molly Gulch, on rim, below Dailies Hill, grassland mix, Blechnum palmiforme, Malaise trap, $\pm 2270 \mathrm{ft} ., 37^{\circ} 11^{\prime} 44^{\prime \prime S} 12^{\circ} 33^{\prime} 53^{\prime \prime W}, 15-21 . i i .2005$, site 7, sample 18, C. HäNEL, 1 ㅇ (pinned).

\section{MUSCIDAE}

\section{Coenosia trina WiedemanN, 1830}

First recorded (as C. humilis Meigen, 1826) from Tristan by Baird (1965: 426) and Holdgate (1965: 397), and from Nightingale by Carvalho \& Couri (1999: 211-212).

Widespread in the Afrotropical region. Adults of its sister-species, the Holarctic and Oriental C. humilis, with which it probably shares its biological features, are voracious predators of other small soft-bodied insects (Evans, 1930; KüHne, 2000). Larvae of humilis are also predaceous, and most probably live in soil. In the laboratory, KüHNE (op. cit.) was able to maintain cultures on a substrate of wood bark fibre to which crushed oats were periodically added, where they fed on introduced prey larvae.

This species was, under the name of multimaculata ADAMs, 1905, ranked as a subspecies of Coenosia humilis MEIGEN by EMDEN (1940: 179) since there were consistent but small differences between European and Afrotropical humilis. It was still ranked as a subspecies of humilis by PONT (1980b: 755), with trina Wiedemann, 1830, listed as a doubtful synonym. Since then, the typeseries of trina has been examined and the availability of this name for the Afrotropical vicariant of Coenosia humilis established (PonT, 1997: 113-114). Study of the present material strongly confirms that trina should be ranked as a species distinct from humilis, based on the characters given by EMDEN (l.c.), especially the slightly longer haired arista in trina, the narrower frons in trina, and the generally more extensive dark dusting on scutellum and abdomen in trina.

461 specimens collected in 2005; 39 on Tristan (21 $\sigma^{\top} \sigma^{\star}, 18$ 우), and 422 on Nightingale

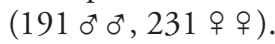


TRISTAN DA CUNHA, west of Edinburgh village, potato patches, cultivated cropland, potatoes, vegetation and cattle grazing, 37 09'06"S 12 34'26"W, 07-12.ii.2005, Malaise, site 2, sample 14c, C. HäNEL, 1 o , 1 † (pinned).

TRISTAN DA CUNHA, up Molly Gulch, on rim, below Dailies Hill, grassland mix, $\pm 2270 \mathrm{ft}$., $37^{\circ} 11^{\prime} 44^{\prime \prime S ~ 12 ³ 3 ' 53 " W, ~ 15-21 . i i .2005, ~ M a l a i s e, ~ s i t e ~ 7, ~ s a m p l e ~ 19, ~ C . ~ H a ̈ N E L, ~} 3$ o $^{\star}$ o $^{\circ}$ (alcohol).

TRISTAN DA CUNHA, Sandy Point, woodland shrub, behind the hut, $\pm 102 \mathrm{ft}$., $37^{\circ} 11^{\prime} 47^{\prime \prime S}$ (dubious) $12^{\circ} 22^{\prime} 61^{\prime \prime} \mathrm{W}, 21 . i i .2005$, site 9, sample 22, C. HäNEL, $17 \sigma^{\star} \sigma^{\star}, 17$ ㅇ ㅇ (alcohol).

NIGHTINGALE, Path up from West Landing, coastal cliffs cave-overhang with tussock,

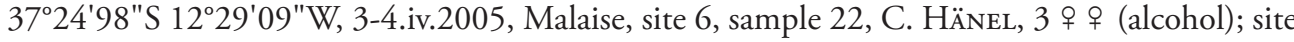
6, sample 23, Malaise, $520^{\star \top} \sigma^{\star}, 77$ 우 우 (alcohol).

NIGHTINGALE, West Road, path inland from landing, tussock grassland some Scirpus and alien spp. in path, $37^{\circ} 25^{\prime} 02^{\prime \prime S ~} 12^{\circ} 28^{\prime} 66^{\prime \prime W}, 28-29$.iii.2005, Malaise, site 7, sample 19b, C. HäNEL, 7 우 우 (alcohol); site 7, sample 21, Malaise, $40^{\star} 0^{*}, 1$ ㅇ (alcohol).

NIGHTINGALE, Herbert's hut site, East landing area, tussock grassland and alien veg. along

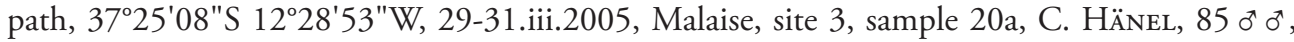
95 우 우 (alcohol).

NIGHTINGALE, 3rd Pond close to top of path, mire wetland, Scirpus spp., fernbush spp. and

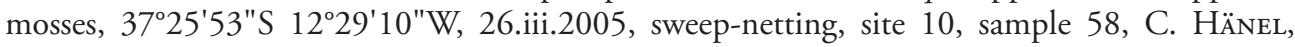

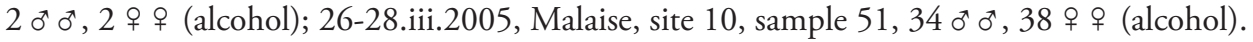

NIGHTINGALE, 1st Pond, furthest from path, mire wetland with pool surrounded by Scirpus spp., 37²6'02"S 12²9'30"W, 30.iii-01.iv.2005, site 8, sample 80c, C. HäNEL, $10^{\star}$ (pinned); and site 8, sample 55, sweep-netting, $13 \sigma^{\top} \sigma^{*}, 8$ ㅇ 우 (alcohol).

\section{Muscina stabulans (FALLÉN, 1817)}

New locality record for Nightingale Island.

First recorded by FREY (1954: 43-44) from Tristan Island. Additional records are reported by BAIRD (1965: 426) and Holdgate (1965: 397).

Cosmopolitan in distribution. Adults are synanthropic. Larvae are saprophagous at first, becoming facultative carnivores later; they breed in decaying animal and vegetable matter, though apparently not excrement, and are recorded as parasitoids of other insects and as occasionally causing myiasis in higher mammals.

Four male specimens collected at Nightingale Island in 2005.

NIGHTINGALE, East Landing area below shacks, coastal boulders with penguin colony and tussock, $37^{\circ} 25^{\prime} 09^{\prime \prime S ~} 12^{\circ} 28^{\prime} 44^{\prime \prime} \mathrm{W}$, Malaise, 1.iv.2005, site 1, sample 1, C. HäNEL, $4 \sigma^{\top} \sigma^{*}$ (alcohol). 
Summary of species recorded from the archipelago

The cosmopolitan Housefly Musca domestica (Linnaeus, 1758) was not amongst the material collected in 2005, but was previously recorded from Tristan Island by Holdgate (1965:397). This species and the four listed above represent the total number of species currently known from the Tristan da Cunha archipelago (see Table 1).

Tab. 1.: Houseflies recorded from the Tristan da Cunha archipelago.

Key: ${ }^{*}=$ New record for the archipelago. $\#$ = New locality record.

\begin{tabular}{|l|l|l|c|c|c|c|}
\hline \multicolumn{3}{|c|}{ Order } & Diptera - Flies & \multicolumn{5}{c|}{ ISLANDS } \\
\hline \multirow{2}{*}{ FAMILY } & GENERA & SPECIES & Tristan & N'gale & Inacces. & Gough \\
\hline \multirow{2}{*}{$\begin{array}{l}\text { Fanniidae } \\
\text { Lesser Houseflies }\end{array}$} & Fannia & albitarsis & $\sqrt{ } *$ & $\sqrt{ } *$ & & \\
\hline & Fannia & canicularis & $\sqrt{ }$ & $\sqrt{ }$ & $\sqrt{ }$ & $\sqrt{ }$ \\
\hline \multirow{2}{*}{$\begin{array}{l}\text { Muscidae } \\
\text { Houseflies }\end{array}$} & Coenosia & trina & $\sqrt{ }$ & $\sqrt{ }$ & & \\
\cline { 2 - 8 } & Musca & domestica & $\sqrt{ }$ & & & \\
\cline { 2 - 8 } & Muscina & stabulans & $\sqrt{ }$ & $\sqrt{ } \#$ & & \\
\hline TOTAL species & & & 5 & 4 & 1 & 1 \\
\hline
\end{tabular}

\section{Discussion}

Care needs to be exercised in the use and interpretation of the 2005 results, in particular in respect of the numbers collected, given the brief, incomplete and $a d$ hoc nature of the sampling during which no quantitative methods were used. Nevertheless, it is interesting to note that Coenosia trina WiedemanN was the dominant species and that it occurred in such abundance, especially on Nightingale. Since the species was not found during the Norwegian Expedition to Tristan da Cunha in 1937-38, and has not yet been recorded from Gough or Inaccessible Island, it seems highly probable that its arrival on the archipelago was by unnatural means at some point prior to its first being collected on Tristan da Cunha in 1962. It was probably introduced via soil or compost from the African mainland, and most probably from South Africa. The Tristan record, one result of an investigation into the effects of the 1961 volcanic eruption, consists only of an indication of its presence in coastal areas mildly or not at all affected by the eruption. These could have been at any of three localities on the Island: the area between Cave Point and Stony Hill in the south, the Settlement in the north-northwest, and Sandy Point on the east coast. The specimens collected during 2005 were found at each of the two latter localities, as well as in one area on the plateau, below Dailies Hill. The greatest number was obtained from Sandy Point, and this despite the fact that collecting lasted only a few hours compared to six days at the Settlement. That the species could already have been abundant on Nightingale when first it was found there on 20 October 1989 is possible, given that the one day opportunity to sample on the Island was restricted to "collecting whatever possible in a short time" (BARBER-James, 2007). The 1989 sample comprised three specimens from the coastal tussock. Sampling during 2005 yielded an abundance in both lowland and upland areas. Little is known about the life history of the species. However, it is clear that this species, the adults of which are predaceous on other small insects, has found a very congenial niche on the islands with few competitors, allowing it to proliferate. It would appear to be most successful in areas unoccupied and little disturbed by humans. By implication, the available food-resource could thus constitute mainly native species. 


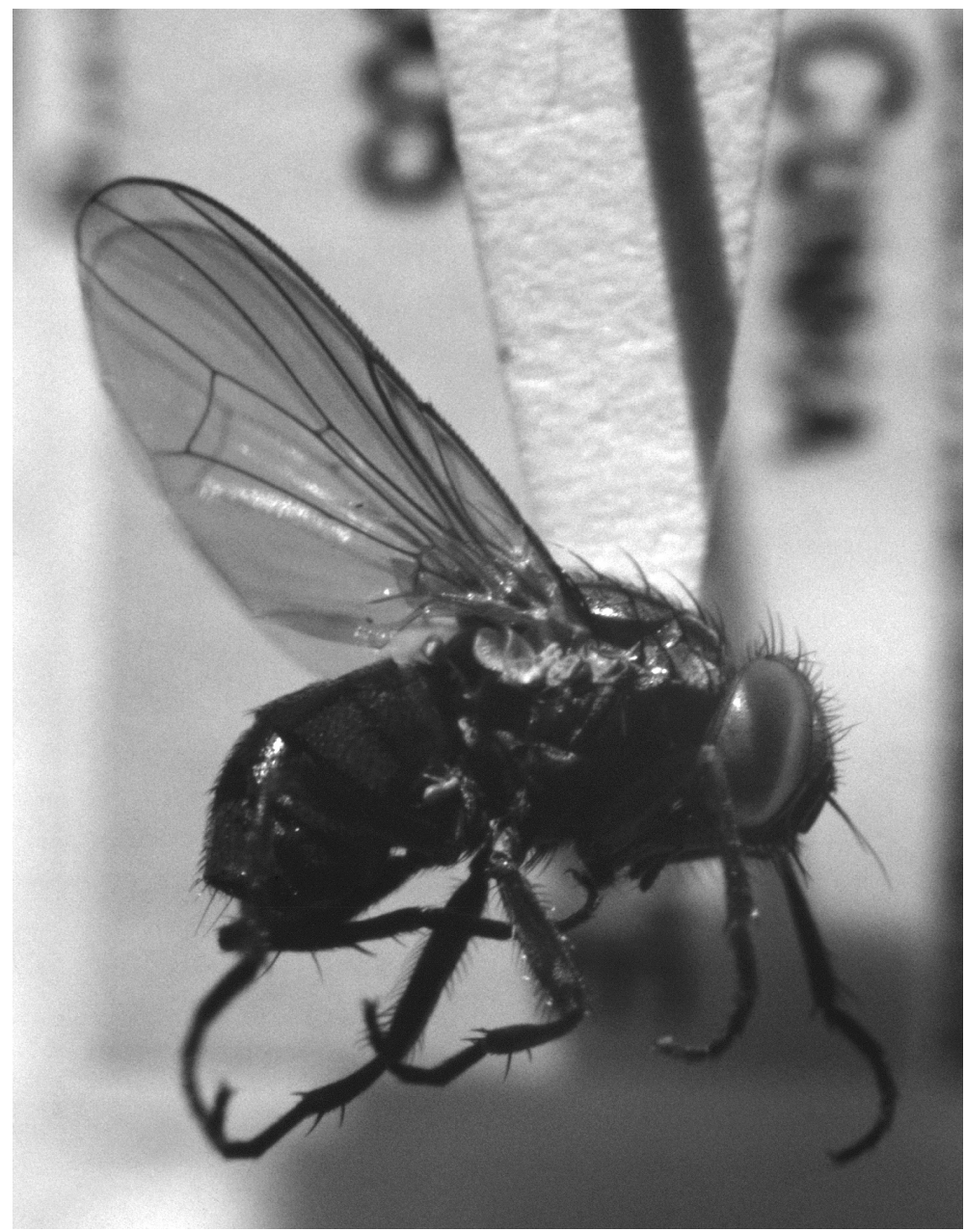

Fig. 3: A Lesser Housefly, Fannia albitarsis Stein, 1911. A lateral view of the female specimen collected from the potato patches on Tristan da Cunha in 2005. Photograph taken by Ch. Hänel.

As with C. trina and the other three species, the occurrence for the first time of Fannia albitarsis STEIN on the archipelago can be attributed to an introduction by unnatural means. This could have been from South Africa, but its exact distribution there is not known and, on the face of it, the most probable point of origin seems to have been its original home in the south of South America, perhaps via the sealers.

Muscina stabulans (FAlléN) and Fannia canicularis (LinnaEus) are abundant synanthropic and hemisynanthropic species in Europe, and have followed Europeans to southern Africa. They are not widespread in South Africa, but, like many introduced synanthropes, they remain concentrated around the coastal ports. They could easily have been transported to Tristan da Cunha via shipping, either from Europe or from South Africa. The fact that Muscina stabulans (FALLÉN) has reached Nightingale could well have been facilitated by inter-island movement, given that the species has been a resident on Tristan da Cunha for at least 70 years and traffic 
between the two islands is an even older practice. That the species could have been introduced independently by visits from outside the archipelago is also possible, especially since these have increased quite substantially in recent years through the tourism industry.

The situation regarding the Housefly Musca domestica Linnaeus is a little puzzling. The only record of its presence on the archipelago is its listing by Holdgate (1965: 397). No description or information could be found in connection with this record. It is presumed to have been found during the 1962 Royal Society's Expedition to Tristan da Cunha, although BAIRD (1965), the entomologist of the expedition, does not list it. No further evidence of its presence has since come to light, nor have the Royal Society Expedition's specimens been found.

\section{Conclusion}

The information presented here is the most up-to-date synthesis for these two families as currently known from the Tristan da Cunha archipelago. However, it cannot be considered to represent the true situation on these islands. With the exception of Gough Island, the invertebrate fauna of which has been most extensively covered, information from the rest of the islands is based only on short and incomplete investigations, none of which were able to survey the islands over all the seasons, or indeed to cover all habitats. The most significant gap in information is Inaccessible Island. Only two collections of any note have been made there, namely the 1989 three-week investigation that focused mainly on the freshwater invertebrates, and the collections made by the Norwegian Expedition to Tristan da Cunha in 1937-38. This is an unsatisfactory situation, particularly as the island has become a prime tourist attraction and is thus potentially subjected to the same uncontrolled import of alien species as is Nightingale Island (see HäNEL \& HaENNI, 2007). The introduction of a species that may thrive on the endemic fauna, such as might account for the success of Coenosia trina Wiedemann on Tristan and Nightingale, could add substantially to altering the fragile ecosystem of the islands and could endanger endemic species. It is paramount that this gap in baseline information should be filled soon. Effective management policies and practices are heavily dependant on knowing what species are on the islands and, when aliens are involved, what implications these may hold.

\section{Acknowledgements}

C.H. thanks the Tristan authorities and James Glass (Agriculture \& Natural Resources Department, Tristan da Cunha) for entrusting the specimens to her for post-project pursuit, and Ashley Kirk-Spriggs (Albany Museum, Grahamstown, South Africa) for sorting the Diptera collection to family level. Funding for the brief 2005 invertebrate project was made available through a small surplus from the larger programme "Empowering the people of Tristan da Cunha", which was financially backed by the UK Government's Darwin Initiative and implemented by the Royal Society for the Protection of Birds, the UK Partner of BirdLife International $\&$ the Tristan Island Government. A.C.P. thanks the Keeper of Entomology and Diptera staff at the Natural History Museum, London, UK, for access to the collection of Fanniidae and Muscidae.

\section{References}

BaIRD, D. E. 1965: The effects of the eruption of 1961 on the fauna of Tristan da Cunha. Part V. Philosophical Transactions of the Royal Society of London B249: 425-434.

Barber-James, H. M. 2007. Freshwater invertebrate fauna of the Tristan da Cunha islands (South Atlantic Ocean), with new records for Inaccessible and Nightingale Islands. - Transactions of the Royal Society of South Africa 62 (1): 24-36. 
Carmichael, D. 1818: Some Account of the Island of Tristan da Cunha and of its Natural Productions. - Transactions of the Linnean Society of London 12: 483-513.

Carvalho, C. J. B. De. \& Couri, M. C. 1999: Coenosia humilis Meigen, 1826 (Dipt., Muscidae), new to Tristan da Cunha Islands, Southern Atlantic Ocean. - Entomologist's monthly Magazine 135: 211-212.

Carvalho, C. J. B. De.; Pont, A. C.; Couri, M. S. \& Pamplona, D. 2003: A catalogue of the Fanniidae (Diptera) of the Neotropical Region. - Zootaxa 219: 1-32.

Christophersen, E. 1940: Tristan da Cunha. Translated by R. L. Benham. - London etc, xii + 243 pp.

Emden, F. I. van. 1940: Muscidae: B. Coenosiinae. - Ruwenzori Expedition 1934-35 2: 91-255. British Museum (Natural History), London.

Evans, A. M. 1930: Observations on the predacious habits and prey of Coenosia humilis, MG. (Anthomyiidae). - Transactions of the Entomological Society of London 78: 325-329.

FreY, R. 1954: Diptera Brachycera und Sciaridae von Tristan da Cunha. - Results of the Norwegian Scientific Expedition to Tristan da Cunha 1937-1938 26: 1-55.

Hänel, C. 2005: Tristan da Cunha Invertebrate Project Report. - Royal Society for Protection of Birds, Sandy, United Kingdom. Internal manuscript: $70 \mathrm{pp}$.

Hänel, C. \& Haenni, J.-P. 2007: First record of a Dung Midge from the South Atlantic island group of Tristan da Cunha (Diptera: Scatopsidae). - Beiträge zur Entomologie 57 (2): 397-400.

Hänel, C. \& Heyne, H. (in press): Ticks of the Tristan da Cunha Archipelago (Acarina: Ixodidae \& Argasidae). - Beiträge zur Entomologie.

Hennig, W. 1955-1964: Muscidae. - In: Lindner, E. (ed.): Die Fliegen der paläarktischen Region 63b: 1110 pp. - Schweizerbart, Stuttgart.

Holdgate, M. W. 1965: The biological report of the Royal Society Expedition to Tristan da Cunha, 1962. Part III. The fauna of the Tristan da Cunha Islands. - Philosophical Transactions of the Royal Society of London B249: 361-402.

Holloway, B. A. 1985: Larvae of New Zealand Fanniidae (Diptera: Calyptrata). - New Zealand Journal of Zoology 11 [1984]: 239-257.

Horn, W. \& Kahle, I. 1935: Über entomologische Sammlungen. (Ein Beitrag zur Geschichte der EntomoMuseologie.) Teil I. - Entomologische Beihefte aus Berlin-Dahlem 2: 1-160.

Jones, A. G.; Chown, S. L.; Webb, T. J. \& Gaston, K. J. 2003: The free-living pterygote insects of Gough Island, South Atlantic Ocean. - Systematics and Biodiversity 1 (2): 213-273.

KüHne, S. 2000: Räuberische Fliegen der Gattung Coenosia Meigen, 1826 (Diptera: Muscidae) und die Möglichkeit ihres Einsatzes bei der biologischen Schädlingsbekämpfung. - Studia dipterologica, Supplement 9: $78 \mathrm{pp}$.

Moseley, H. N. 1892: Tristan da Cunha, Inaccessible Island, Nightingale Island. - In: Moseley, H. N., M. A., F. R. S., late fellow of Exeter College, Oxford. Late Linacre Professor of Human and comparative anatomy in the University of Oxford: A Naturalist on the "Challenger." An account of observations made during the voyage of H. M. S. "Challenger" round the world in the years 1872-1876, under the command of Capt. Sir G. S. Nares, R. N., K. G. B., F. R. S., and Capt. F. T. Thomson, R. N. - T. Werner Laurie Ltd., London: 93-118 pp.; 4 plates.

Oldroyd, H. 1958: Diptera-Cyclorrhapha from Gough Island, South Atlantic. - Proceedings of the Royal Entomological Society of London (A) 33 (4/6): 76-80.

Pont, A. C. 1977: La Faune Terrestre de l'Ile de Saint-Hélène, III. 29. Fam. Muscidae (including Anthomyiidae). - Annales, Musée Royal de l'Afrique Centrale, Série in-8 (Sciences Zoologiques) 215: 121-141.

Pont, A. C. 1980a: Family Fanniidae. - In: Crosskey, R. W. 1980 (ed.): Catalogue of the Diptera of the Afrotropical Region, 1437 pp. - British Museum (Natural History), London: 719-720.

Pont, A. C. 1980b: Family Muscidae. - In: Crosskey, R. W. 1980 (ed.): Catalogue of the Diptera of the Afrotropical Region, 1437 pp. - British Museum (Natural History), London: 721-761. 
Pont, A. C. 1989: Family Fanniidae. - In: Evennuis, N. L. (ed.): Catalog of the Diptera of the Australasian and Oceanian Regions. - Special Publications, Bernice Pauahi Bishop Museum 86: 700-701, 804. - Bishop Museum Press, Honolulu, and E. J. Brill, Leiden.

Pont, A. C. 1997: The Muscidae and Fanniidae (Insecta, Diptera) described by C. R. W. Wiedemann. - Steenstrupia 23: 87-122.

Pont, A. C. 2006. A new species of Fannia Robineau-Desvoidy, 1830 from Madagascar and La Réunion (Diptera: Fanniidae). - African Invertebrates 47: 315-319.

Pont, A. C. \& Carvalho, C. J. B. De. 1994: Neotropical Fanniidae (Diptera): a key to the Fannia anthracinagroup. - Entomologist's monthly Magazine 130 (3): 229-238.

Royal Society for the Protection of Birds [RSPB]. 2004-2005: Empowering the People of Tristan da Cunha to Implement the CBD - Second Annual Report. - RSPB in Partnership with Tristan Island Government, the University of Cape Town \& BirdLife South Africa, pp 1-11 + 11 Annexes.

Ryan, P. \& Glass, J. 2007. The island setting. - In: Ryan, P. 2007 (ed.): Field guide to the animals and plants of Tristan da Cunha and Gough Island. - Pisces Publications, Newbury, for the Tristan Island Government: 13 pp.; 26 plates.

Willemöes-Suhm, R. von 1876: IV. Preliminary Report to Professor Wyville Thomson, F.R.S., Director of the Civilian Scientific Staff, on Observations made during the Earlier Part of the Voyage of H.M.S.. 'Challenger'. - Proceedings of the Royal Society of London 24: 569-585.

\section{Authors' addresses:}

Christine Hänel

P. O. Box 829

Stellenbosch 7599

South Africa

e-mail: chrishanel@yahoo.com
Subject editor:

Adrian C. Pont

Dr. J. Savage
Oxford University

Museum of Natural History

Parks Road

Oxford OX1 3PW, United Kingdom

e-mail: pont.muscidae@btinternet.com 